EUROPA REGIONUM TOM XXIII ROK 2015

DOI: $10.18276 /$ er.2015.23-05

\author{
BoguSŁaW SAWICKI, MaRTA KULAWCZUK \\ Uniwersytet Przyrodniczy w Lublinie
}

\title{
Wybrane cechy ilościowe i jakościowe ruchu turystycznego w „Chełmskich Podziemiach Kredowych - Labirynt”
}

\section{Wprowadzenie}

R uch turystyczny należy rozumieć jako zjawisko o charakterze społeczno 2 -ekonomicznym. G. Gołembski ${ }^{1}$ podaje za Opaschowskim, że od lat 80 ubiegłego wieku omawiane zjawisko weszło w trzecią fazę rozwoju, która charakteryzuje się coraz wyraźniej akcentowanymi motywami wyjazdów zaliczanymi do realizacji potrzeb psychicznych, opinia ta znajduje potwierdzenie w opracowaniu R.E. Bernackiej ${ }^{2}$. Poza tym w obecnej dobie w rozwoju ruchu turystycznego nie można mijać koncepcji rozwoju zrównoważonego ${ }^{3}$ rozumianego jako „rozwój społeczno-gospodarczy zharmonizowany ze środowiskiem przyrodniczym"4. Należy również podkreślić, że ruch turystyczny jest głównym miernikiem funkcjonujących atrakcji turystycznych ${ }^{5}$. Jednocześnie warto wspomnieć walory turystyczne, dostępność transportową oraz infrastrukturę turystyczną jako powszechnie wymieniane czynniki wpływające na wielkość i charakter ruchu turystycznego ${ }^{6}$. Zagadnienie to jest jednak znacznie bardziej

\footnotetext{
${ }^{1}$ G. Gołembski, Kompedium wiedzy o turystyce, Wydawnictwo Naukowe PWN, Warszawa, 2005, s. 26-27.

${ }^{2}$ R. E. Bernacka, Funkcje turystyki kulturowej na obszarach wiejskich w kontekśsie psychologicznym, w: red B. Sawicki, J. Janicka, Wielowymiarowe aspekty turystyki kulturowej. Uniwersytet Przyrodniczy w Lublinie, Lublin 2011, s. 56.

${ }^{3} \mathrm{~S}$. Zaremba-Warnke, Marketing jako narzędzie realizacji ścieżek strategicznych ekonomii zrównoważonego rozwoju, Annual Set The Environment Protection, Vol. 15, 2851, 2013.

${ }^{4}$ B. Piontek, Koncepcja rozwoju zrównoważonego i trwałego Polski, Wydawnictwo Naukowe PWN, Warszawa 2002, s. 16.

${ }^{5}$ Z. Kruczek, Atrakcje turystyczne, Proksenia, Kraków 2011, s. 16-17. 2006, s. 14.

${ }^{6}$ B. Meyer, Obstuga ruchu turystycznego, Wydawnictwo Naukowe PWN, Warszawa
} 
złożone, bowiem bez odpowiednio opracowanego ${ }^{7}$ i zarządzanego ${ }^{8}$ produktu turystycznego cieszącego się nawet dużym powodzeniem wśród turystów, bardzo trudno jest doprowadzić do istnienia marki w turystyce regionalnej czy krajowej ${ }^{9}$.

W kontekście powyższych rozważań cechy jakościowe ruchu turystycznego trzeba rozpatrywać od strony obsługi związanej z wewnętrzną organizacją przedsiębiorstwa turystycznego, transportem oraz uwarunkowaniami rynkowy$\mathrm{mi}^{10}$. Warto jednak zwrócić uwagę także na miejsce generowania ruchu turystycznego oraz jego strukturę, a w tym cechy socjologiczne.

Celem niniejszego opracowania jest analiza i ocena liczby turystów odwiedzających „Chełmskie Podziemia Kredowe - Labirynt” w różnych konfiguracjach czasowych oraz ich cech socjologicznych, co powinno stanowić punkt wyjścia do planowania strategicznego rozwoju turystyki w regionie, a w dalekiej perspektywie także w całym kraju.

\section{Metody badawcze i charakterystyka badanego obszaru oraz obiektu}

W opracowaniu analizowano wyniki wtórne (dokumenty z przedsiębiorstwa „Chełmskie Podziemia Kredowe - Labirynt”) oraz wyniki pierwotne, które uzyskano metodą sondażu diagnostycznego, a w tym techniką ankietową (turyści) i wywiadu bezpośredniego (pracownicy turystyki, samorządu terytorialnego oraz organizacji pozarządowych). Badania ankietowe i wywiady przeprowadzono w latach 2013-2014. Ogółem rozprowadzono 400 ankiet, a otrzymano 384 poprawnie wypełnione kwestionariusze. Analizowano dokumenty sprzedaży biletów w latach 2001-2013.

Chełm leży we Wschodniej Polsce w odległości $230 \mathrm{~km}$ od Warszawy, $71 \mathrm{~km}$ od Lublina, $65 \mathrm{~km}$ o Zamościa i $29 \mathrm{~km}$ od przejścia granicznego z Ukrainą w Dorohusku. Miasto zamieszkuje 68160 osób, co stawia go na drugim miejscu pod względem liczby mieszkańców w województwie lubelskim,

${ }^{7}$ J.J. Brdulak, Zarzqdzanie wiedza a proces innowacji produktu. SGH w Warszawa, Warszawa 2005, s. 52. B. Marciszewska, Produkt turystyczny a ekonomia doświadczeń. C.H. Beck, Warszawa 2010, s. 45.

${ }^{8}$ L. Pender,R. Sharpley, Zarzqdzanie turystyka, Polskie Wydawnictwo Ekonomiczne, Warszawa 2008, s. 35.

${ }^{9}$ L. Worobjow, K. Ertmańska, Marka kraju a marka produktu - wybrane zagadnienia, Europa Regionum t. XVII, Wydawnictwo Naukowe Uniwersytetu Szczecińskiego, Szczecin 2013, s. 29.

${ }^{10}$ A. Panasiuk, Jakość obstugi ruchu turystycznego, w: Obstuga ruchu turystycznego. red. B. Meyer, Wydawnictwo Naukowe PWN, Warszawa, s. 226. 
które w Krajowej Strategii Rozwoju Regionalnego (rok 2010) zaliczono do obszarów problemowych, na których trzeba prowadzić działania zapobiegające ich marginalizacji. Do tej grupy zaliczono także województwa: warmińskomazurskie, podlaskie, podkarpackie i świętokrzyskie ${ }^{11}$. Z badań przeprowadzonych przez A. i A. Malkowskich ${ }^{12}$ wynika, że w roku 2004 w ocenie rozwoju społeczno-gospodarczego mierzonego wskaźnikiem Perkala, województwo lubelskie plasowało się na 15 miejscu (wskaźnik Perkala 0,19 - dostateczny). Niestety po siedmiu latach (rok 2011) miejsce pozostało to samo, lecz wskaźnik Perkala zmalał do $-0,31$ co oznacza poziom rozwoju niedostateczny. Sytuacja jest gorsza tylko w województwie łódzkim. Biorąc pod uwagę walory przyrodnicze $^{13}$ oraz gospodarkę rolną ${ }^{14}$, na Lubelszczyźnie należałoby szczególnie dbać o wymieniony potencjał i rozwijać sektor gospodarki turystycznej.

Miasto Chełm leży na skałach kredowych wytworzonych w okresie jurajskim ery mezozoicznej, których grubość dochodzi do 800 metrów. Od wieków ceniono wartość chełmskiej kredy ze względu na 97\% zawartości węglanu wapnia $\left(\mathrm{CaCO}_{3}\right)$. Zaczęto ją wydobywać w XIII wieku, bowiem była cennym surowcem w ceramice i budownictwie, służyła do wyrobu farb, barwników organicznych, kolorowych kredek, kredy piszącej, lekarstw i pudrów kosmetycznych. Tak powstały podziemia kredowe mające kilkadziesiąt kilometrów długości i rozciągające się pod całą miejską starówką, a sięgające do głębokości ponad 20 metrów. Należy zaznaczyć, że od czasów najdawniejszych „chełmskie górnictwo kredowe” nie było działalnością legalną. Górnikami zawsze byli zwykli mieszkańcy Chełma, którzy drążyli korytarze wydobywane pod swoimi i sąsiedzkimi domami. Skutkiem takiej działalności w roku 1945 około $70 \%$ chełmskich domów nadawało się do remontu skutkiem naruszenia konstrukcji nośnej. Takie były uwarunkowania powstania jedynej w swoim rodzaju chełmskiej kopalni kredy. W roku 1994 kopalnia została wpisana do rejestru jako zabytek trzeciej kasy, stanowiący unikatową pozostałość górnictwa kredowego w Europie.

${ }^{11}$ J. Bański, Obszar problemowy - koncepcje i kryteria identyfikacji, Departament Programów Ponadregionalnych, Ministerstwo Rozwoju Regionalnego, Warszawa 2011, s. 15.

${ }^{12}$ A. Malkowski, A. Malkowska, Rozwój społeczno-gospodarczy obszarów peryferyjnych na przykładzie wschodniego pogranicza Polski, Europa Regionum t. XVI Wydawnictwo Naukowe Uniwersytetu Szczecińskiego, Szczecin 2013, s. 339.

${ }^{13}$ B. Sawicki, M. Harasimiuk, Rola obszarów chronionych w rozwoju edukacji, turystyki i gospodarki, Uniwersytet Przyrodniczy w Lublinie, Lublin 2014, s. 149.

${ }^{14}$ B. Sawicki, A.K. Mazurek-Kusiak, Agroturystyka $w$ teorii $i$ praktyce. Uniwersytet Przyrodniczy w Lublinie, Lublin 2010, s. 17. 
W podziemiach panuje stała temperatura $+9^{\circ} \mathrm{C}$, a wilgotność oscyluje na poziomie $70-85 \%$. W roku 1974 w podziemnym labiryncie korytarzy kredowych utworzono oświetloną trasę turystyczną o długości około $2 \mathrm{~km}$. Turystyczne zwiedzanie podziemi trwa około 50 min. Produkt turystyczny pod nazwą „Chełmskie Podziemia Kredowe - Labirynt” można zwiedzać przez cały rok (wyjątek stanowi kilka świąt). Turyści indywidualni mogą korzystać z wejść o godz. 11.00,13.00, 16.00. Grupy liczące ponad 20 osób powinny dokonać wcześniejszej rezerwacji. Zwiedzanie jest możliwe tylko z przewodnikiem.

\section{Wyniki badań i dyskusja}

Z przeprowadzonych badań wynika, że ruch turystyczny w „Chełmskich Podziemiach Kredowych - Labirynt” w latach 2001-2006 wzrastał nierównomiernie, bowiem wykazano tu jego wahania wynoszące w kolejnych latach od +16 do $-11 \%$. Wyjątkowo wysoki (25\%) wzrost zanotowano w roku 2007, lecz w ostatnich dwóch latach badań (2012-2013) były to już tylko wzrosty 3-4\%. Porównując jednak rok 2001 i rok 2013 wykazano wzrost ruchu z 13260 do 22 458, co w przeliczeniu na procenty stanowi 69\% (rys. 1). Z badań ankietowych prowadzonych wśród turystów odwiedzających badany obiekt w latach 2013-2014 wynika, że 95,8\% spośród nich należało do odwiedzających jednodniowych. Natomiast na podstawie wywiadów ustalono, że zdecydowane zwiększenie ruchu turystycznego w latach 2007-2013 należy wiązać ze zmianą działań marketingowych prowadzonych przez firmę zarządzającą omawianą podziemną trasą turystyczną. Dla porównania warto podać, że w porównywalnym okresie liczba turystów korzystających z obiektów noclegowych w Polsce wzrosła o $35 \%$, a w województwie lubelskim o $20 \%{ }^{15}$.

${ }^{15}$ M. Oesterreich, Statystyczna analiza sezonowości ruchu turystycznego w wybranych województwach w latach 2004-2011. Europa Regionum t. XVII, Wydawnictwo Naukowe Uniwersytetu Szczecińskiego, Szczecin, 2013, s. 307. 


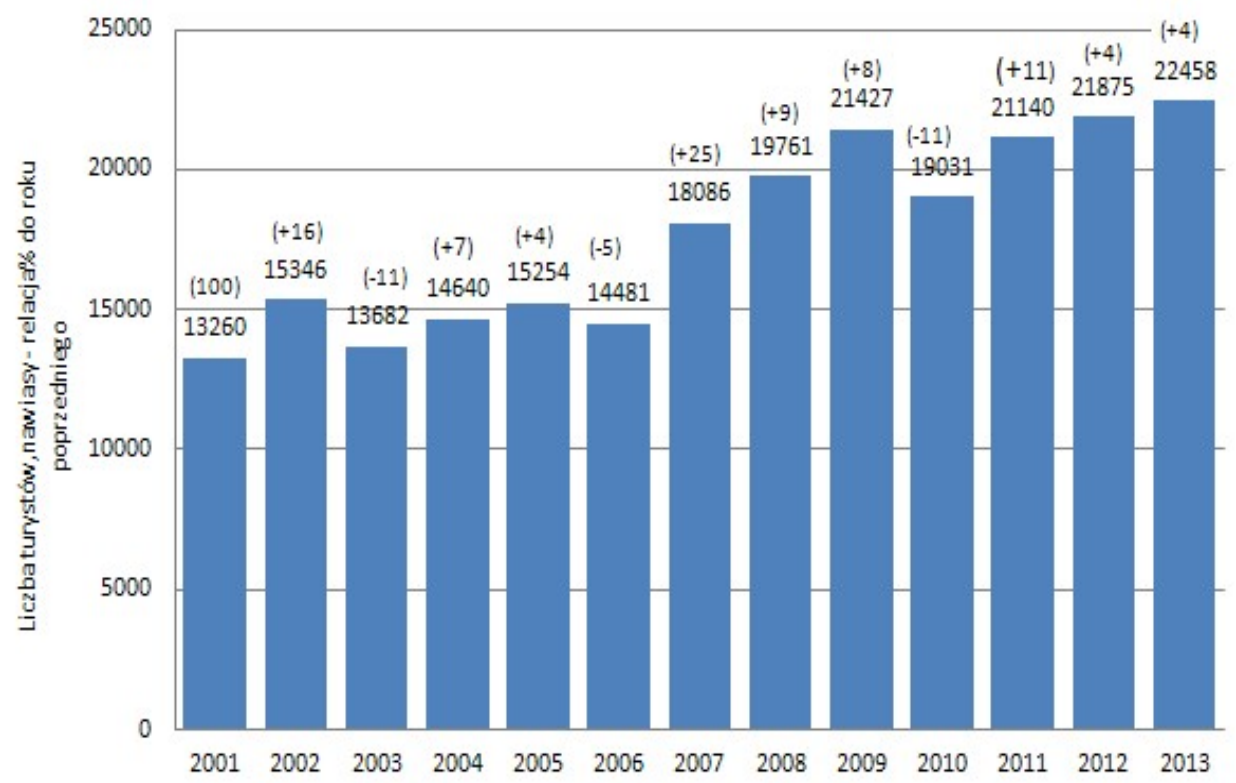

Rysunek 1. Liczba turystów odwiedzających „Chełmskie Podziemia Kredowe - Labirynt" w latach 2001-2013

Źródło opracowanie własne na podstawie wyników wtórnych (sprzedaż biletów).

Badając sezonowość ruchu turystycznego w „Chełmskich Podziemiach Kredowych - Labirynt" stwierdzono, że kumuluje się on głównie w miesiącach maj-sierpień stanowiąc od 68 do $72 \%$ ruchu całorocznego (rys. 2). Jest to tendencja znana $\mathrm{w}$ turystyce związanej z walorami przyrodniczymi, jednak biorąc pod uwagę całoroczną stałą temperaturę w podziemnej trasie oraz całoroczne funkcjonowanie tej wyjątkowej w skali europejskiej atrakcji, to można byłoby popracować nad złagodzeniem tak znaczącego zjawiska sezonowości. 


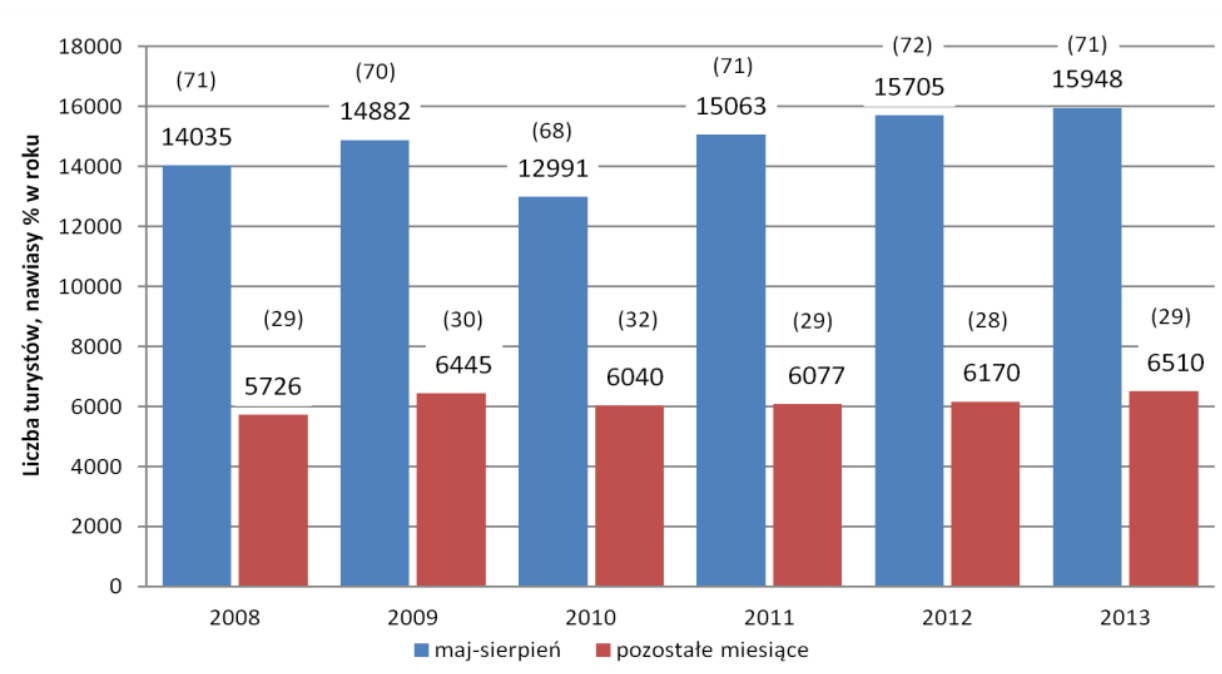

Rysunek 2. Liczba turystów odwiedzających „Chełmskie Podziemia Kredowe - Labirynt" w latach 2001-2013

Źródło: opracowanie własne na podstawie wyników wtórnych (sprzedaż biletów).

Z przeprowadzonych wywiadów wynika, że podziemna trasa turystyczna funkcjonuje jako samodzielny produkt turystyczny. Tymczasem powinna wchodzić do pakietu opracowanego przez touroperatorów i powszechnie sprzedawanego w biurach turystycznych. W promocję tak rozumianego produktu powinien być włączony lokalny i regionalny samorząd terytorialny oraz organizacje pozarządowe $^{16}$, a w promocję zagraniczną powinna być zaangażowana Polska Organizacja Turystyczna ${ }^{17}$. Poza tym podmiot zarządzający produktem „Chełmskie Podziemia Kredowe - Labirynt" powinien działać ustawicznie na polu innowacyjności i podejmować próby działania $\mathrm{w}$ sieci organizacyjnej ${ }^{18}$. Tymczasem z przeprowadzonych wywiadów wynika, że ta działalność jest zbyt statyczna.

Z badań ankietowych wynika, że w strukturze wiekowej odwiedzających omawiany obiekt dominują osoby w przedziale wiekowym od 20 do 59 lat (70\%), a dzieci i młodzież do 19 roku życia stanowią tylko $18 \%$ ruchu turystycznego (rys. 3).

\footnotetext{
${ }^{16}$ I. Jędrzejczyk, Uwarunkowania ekonomiczne i społeczne działalności organizacji pozarzadowych na rzecz rozwoju turystyki, w: red. B. Sawicki, A.Nizioł, M. Obodyński, Rola organizacji pozarzadowych w rozwoju i promocji turystyki. Wydawnictwo Uniwersytetu Rzeszowskiego, Rzeszów 2012, s. 23-25.

${ }_{17}$ J.Ch. Holloway, Ch. Robinson, Marketing $w$ turystyce, Polskie Wydawnictwo Ekonomiczne, Warszawa 1997, s. 185. s. $260-261$.

R. Domański, Geografia Ekonomiczna. Wydawnictwo Naukowe PWN, Warszawa 2006,
} 


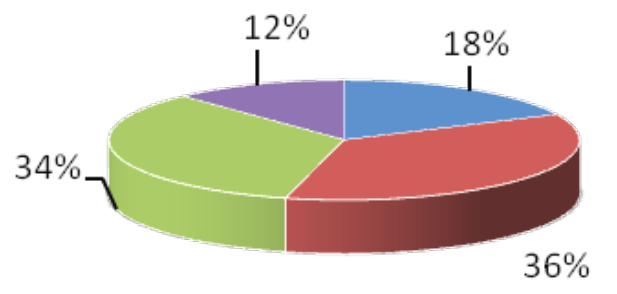

$$
\begin{aligned}
& \square \text { do } 19 \\
& \square \text { 20-29 } \\
& \square \text { 30-59 } \\
& \square \text { powyżej } 60
\end{aligned}
$$

Rysunek 3. Struktura wiekowa turystów odwiedzających „Chełmskie Podziemia Kredowe - Labirynt". Lata 2013-2014

Źródło: opracowanie własne na podstawie przeprowadzonych badań ankietowych.

Biorąc pod uwagę pochodzenie turystów stwierdzono, że $81,8 \% \mathrm{z}$ nich przybywa z województwa lubelskiego, jest to wiec regionalny produkt turystyczny (rys. 4). Sytuacja wyglądała jeszcze gorzej, kiedy w ankiecie zapytano o dokładne miejsce zamieszkania, bowiem $66,4 \%$ odwiedzających pochodziło z powiatu chełmskiego oraz z powiatów przylegających, co czyni ten produkt bardziej lokalnym. Tak nie powinno być, bowiem omawiana trasa turystyczna ma wszelkie cechy markowego produktu krajowego, a nawet zadatki na produkt europejski ${ }^{19}$.

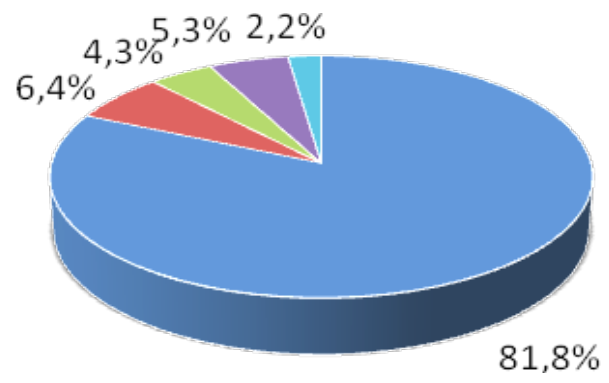

$$
\begin{aligned}
& \square \text { woj. lubelskie } \\
& \square \text { woj. mazowieckie } \\
& \square \text { woj. małopolskie } \\
& \square \text { woj. inne } \\
& \square \text { inne kraje }
\end{aligned}
$$

Rysunek 4. Struktura wiekowa turystów odwiedzających „Chełmskie Podziemia Kredowe - Labirynt”. Lata 2013-2014

Źródło: opracowanie własne na podstawie przeprowadzonych badań ankietowych.

${ }^{19}$ A. Weidenfeld, Ikonicity and Flagsshipness of Tourist Attractions. Annals of Tourism Research 2010, Vol. 37, No. 3, s. 852. 


\section{Podsumowanie}

Z przeprowadzonej analizy badawczej wynikają następujące wnioski:

- ilościowo ruch turystyczny w „Chełmskich Podziemiach Kredowych Labirynt" systematycznie wzrasta, lecz wobec istniejącego potencjału nie jest to wzrost znaczący, bowiem w latach 2012-2013 wynosił od 3 do 4\%, programowo są tutaj tylko trzy wejścia turystów w ciagu dnia, a więc przy pracy ośmiogodzinnej można ten ruch zwiększyć o kolejne 5 wejść $(62,5 \%)$,

- występuje duża sezonowość ruchu turystycznego, ponieważ od 68 do $72 \%$ odwiedzających przybywa tutaj w okresie od maja do sierpnia, tymczasem stała temperatura w podziemiach $\left(+9^{\circ} \mathrm{C}\right)$ powinna sprzyjać wizytom całorocznym, stąd konieczne jest opracowanie atrakcyjnego i złożonego produktu turystycznego na wszystkie sezony,

- dzieci i młodzież stanowią zaledwie 18\% ruchu turystycznego, należy więc poczynić działania marketingowe w kierunku rozwoju turystyki edukacyjnej,

- omawiana atrakcja jest praktycznie produktem lokalnym, gdyż $66,4 \%$ ruchu turystycznego generuje powiat chełmski i powiaty ościenne. Jest ona ewenementem na skalę krajową i europejską, tymczasem jest lokalnym samodzielnym produktem turystycznym. Należy więc uczynić z tej atrakcji jeden $\mathrm{z}$ ważnych elementów nie tylko regionalnego, ale markowego krajowego i złożonego produktu, który będzie promowany w skali europejskiej. Należy w tym celu zintegrować działania wszelkich organizacji mających wpływ na rozwój turystyki.

\section{Bibliografia}

Altkorn J., Marketing w turystyce, Wydawnictwo Naukowe PWN, Warszawa 1995.

Bański J., Obszar problemowy - koncepcje i kryteria identyfikacji, Departament Programów Ponadregionalnych, Ministerstwo Rozwoju Regionalnego, Warszawa 2011.

Bernacka R.E., Funkcje turystyki kulturowej na obszarach wiejskich $w$ kontekśsie psychologicznym, w: red. B. Sawicki, J. Janicka, Wielowymiarowe aspekty turystyki kulturowej. Wyd. Uniwersytet Przyrodniczy w Lublinie, Lublin 2011.

Brdulak J.J., Zarzqdzanie wiedzq a proces innowacji produktu. SGH w Warszawie, Warszawa 2005.

Domański R., Geografia Ekonomiczna, Wydawnictwo Naukowe PWN, Warszawa 2006. 
Gołembski G., Kompedium wiedzy o turystyce, Wydawnictwo Naukowe PWN, Warszawa 2005.

Holloway J.Ch., Robinson Ch., Marketing $w$ turystyce, Polskie Wydawnictwo Ekonomiczne, Warszawa 1997.

Jędrzejczyk I., Uwarunkowania ekonomiczne i społeczne działalności organizacji pozarzqdowych na rzecz rozwoju turystyki, w: red. B. Sawicki, A. Nizioł, M. Obodyński, Rola organizacji pozarzadowych w rozwoju i promocji turystyki, Wydawnictwo Uniwersytetu Rzeszowskiego, Rzeszów 2012.

Kruczek Z., Atrakcje turystyczne, Proksenia, Kraków 2011.

Malkowski A., Malkowska A., Rozwój spoteczno-gospodarczy obszarów peryferyjnych na przyktadzie wschodniego pogranicza Polski, Europa Regionum t. XVI, Wydawnictwo Naukowe Uniwersytetu Szczecińskiego, Szczecin 2013.

Marciszewska B., Produkt turystyczny a ekonomia doświadczeń, C.H. Beck, Warszawa 2010.

Meyer B., Obstuga ruchu turystycznego. Wydawnictwo Naukowe PWN, Warszawa 2006.

Mikuta B., Świątkowska M., Organizacja ustug turystycznych i hotelarskich, SGGW 2008.

Oesterreich M., Statystyczna analiza sezonowości ruchu turystycznego w wybranych województwach w latach 2004-2011, Europa Regionum t. XVII, Wydawnictwo Naukowe Uniwersytetu Szczecińskiego, Szczecin 2013.

Panasiuk A., Jakość obstugi ruchu turystycznego, w: red. B. Meyer, Obstuga ruchu turystycznego. Wydawnictwo Naukowe PWN, Warszawa 2006.

Pender L., Sharpley R., Zarzqdzanie turystyka, Polskie Wydawnictwo Ekonomiczne, Warszawa 2008.

Piontek B., Koncepcja rozwoju zrównoważonego i trwałego Polski, Wydawnictwo Naukowe PWN, Warszawa 2002.

Sawicki B., Harasimiuk M., Rola obszarów chronionych w rozwoju edukacji, turystyki i gospodarki, Uniwersytet Przyrodniczy w Lublinie, Lublin 2014.

Sawicki B., Mazurek-Kusiak A.K., Agroturystyka w teorii i praktyce, Uniwersytet Przyrodniczy w Lublinie, Lublin 2010.

Weidenfeld A., Ikonicity and Flagsshipness of Tourist Attractions. Annals of Tourism Research, 2010, Vol. 37. No. 3.

Worobjow L., Ertmańska K., Marka kraju a marka produktu - wybrane zagadnienia, Europa Regionum t. XVII, Wydawnictwo Naukowe Uniwersytetu Szczecińskiego, Szczecin 2013.

Zaremba-Warnke S., Marketing jako narzędzie realizacji ścieżek strategicznych ekonomii zrównoważonego rozwoju, Annual Set The Environment Protection, 2013, Vol. $15,2851$. 


\title{
Selected quantitative and qualitative features of tourist traffic in The Chalk Undergrounds of Chełm - The Labyrinth
}

\begin{abstract}
Summary
This study presents results of research in selected quantitative and qualitative features of "The Chalk Undergrounds - The Labyrinth"

This work made use of already existing research results from the period of 20012013 and primary findings obtained through a diagnostic survey during the period of 2013-2014. The conducted analyses indicate that tourist traffic underwent systematic increase in the examined period, however not in direct proportion to its inherent potential.

It is actually a local product functioning as a single local tourist attraction, whereas it should be part of a renowned domestic product with a European scale of promotion.

This, however, requires an application of innovative approach and appropriate management of knowledge in the process of branding.
\end{abstract}

Translated by: Grzegorz Knyś 